\title{
Does Household Income Matter for Children's Schooling? Evidence for Rural Sub-Saharan Africa
}

\author{
Michael Grimm ${ }^{1}$ \\ International Institute of Social Studies, Erasmus University Rotterdam, The \\ Netherlands
}

(Forthcoming in Economics of Education Review, 30(4): 740-754.)

\begin{abstract}
Household income has been shown to matter for children's school enrolment, in particular in settings where households face tight liquidity constraints caused by the lack of insurance and limited possibilities to smooth consumption through credit and savings. However, so far only few studies have made an effort to quantify the income elasticity of school enrolment, in particular in the Sub-Saharan African context. The empirical problem in identifying the causal impact of income on enrolment is to control for parental ability, which is largely unobserved, and to deal with reverse causality and measurement error. This paper uses for identification a natural experiment in Burkina Faso, a country with particularly low enrolment rates. The results show that naive estimates largely underestimate the true income elasticity of school enrolment. The results can provide a basis for safety net policies.
\end{abstract}

Key words: School enrolment, Economic crisis, Sub-Saharan Africa.

JEL codes: I21, O12, Q12.

\footnotetext{
${ }^{1}$ International Institute of Social Studies, Erasmus University Rotterdam, Kortenaerkade 12, 2518 AX The Hague, The Netherlands, Phone: +31-70-4260694, Email: grimm@iss.nl. I thank the Institut National de la Statistique et de la Démographie (INSD) in Burkina Faso for providing the household survey data. The paper also benefited from very useful comments by two anonymous referees, the editor, Ron Zimmer as well as François Bourguignon, Denis Cogneau, Rémi Jedwab, Bakary Kindé, Robert Sparrow, Joachim Wolff and participants at seminars and conferences in Ouagadougou (GTZ-MEF), Zürich (VfS), Accra (PEGNet), Essen (VfS-PopEcon), Tinbergen Institute, IDS-Sussex, Göttingen University, Brunel UniversityLondon and Frankfurt University. All remaining errors are my own. Funding for this research from the German Research Foundation (DFG) is gratefully acknowledged [grant number: GR3097/1-1].
} 


\section{Introduction}

In many parts of Sub-Saharan Africa, in particular in Western-Africa, in rural areas and for girls, school enrolment rates are very low. Very often policy interventions designed to increase enrolment in this region still have a strong emphasis on the supply side, such as enhancing school construction, the training of teachers and revisions of the curriculum. However, a number of studies have emphasized the importance of household income when parents have to decide whether or not to send their children to school (e.g. Deininger 2003; Glewwe and Jacoby, 2004; Cogneau and Jedwab, 2008). Household income has been shown to matter in particular in settings where households face liquidity constraints, caused by the lack of insurance and limited possibilities to smooth consumption through credit and savings (e.g. Jacoby and Skoufias, 1997; Beegle, Dehejia and Gatti, 2006). In such a context recurrent shocks to household income frequently force households to withdraw their children from school or not to enroll them in the first place (e.g. Jensen, 2000; Yamano, Alderman and Christiaensen, 2005).

However, so far not much effort has been made to quantify the causal impact of income on school enrolment in the Sub-Saharan African context. A notable exception is Cogneau and Jedwab (2008). The empirical problem in analyzing the relationship between school attainment and family income is to control for parental ability, which is largely unobserved, and to deal with reverse causality and measurement error.

Now and in the coming years a lot of resources are being allocated by governments and donors to increase school enrolment in that region. ${ }^{2}$ Hence information about the income effects on schooling decisions is important in deciding how to spend these resources in the most effective way. Well designed and targeted policies that support income directly or indirectly, for instance through investments in agricultural productivity or policies that reduce the direct or indirect costs of schooling, have to complement supply-side orientated policies and need to be based on rigorous evidence with respect to the income elasticity of enrolment. This elasticity is also important to design safety nets that could protect children's schooling in case households are hit by income shocks due, for instance, to weather fluctuations, crop disease, illness or mortality.

To identify the causal impact of household income on investments in children's education in the context of Sub-Saharan Africa, I rely on a natural experiment in Burkina Faso, a poor landlocked and largely agricultural economy in the middle of West-Africa. I use the fact that cotton farmers on the one hand and food crop farmers on the other hand experienced quite different income movements in the mid-nineties. The findings of this paper suggest that a decline in income by ten percent causes a decline in enrolment rates among children aged six to thirteen by about 2.5 percentage points for boys and 3 percentage points for girls. This impact is more than three times higher than what a simple OLS regression would suggest.

The remainder of the paper is organized as follows. Section 2 provides a

\footnotetext{
${ }^{2}$ About 3.5 Billion USD (2007 prices and exchange rates) of bilateral and multilateral aid are currently allocated to the education sector (OECD International Development Statistics, see http://www.oecd.org).
} 
short review of the relevant literature. Section 3 discusses the economic context in Burkina Faso and provides some information about the education system. Section 4 presents some theoretical considerations underlying the empirical part of the paper. Section 5 presents the data source. Section 6 first analyzes descriptively the effect of an income shock on schooling and child work and then estimates the causal effect of income on school enrolment. Section 7 concludes.

\section{A review of the literature}

Various papers have analyzed the impact of transitory and unanticipated income shocks on outcomes related to children's education and health in poor rural settings. The theoretical background of these papers is that under liquidity constraints, caused by the lack of insurance and limited possibilities to smooth consumption through credit and savings, the standard human capital investment model of child labor and schooling decisions introduced by Schultz (1960) and formalized by Ben-Porath (1967) does not apply. As pointed out by Baland and Robinson (2000), if parents face such constraints then, in the event of a negative shock, they have to trade off the future benefits of educating their children against their current consumption needs. Therefore children are either not enrolled into or drop out of school in order to save on the direct costs of schooling (such as school fees, textbooks and uniforms), to contribute to household income and to help maintain current consumption, even if the long term return on child labor is below the return on education.

In what follows, two related strands of the literature are briefly reviewed: First, research that analyzes the impact of shocks, in particular rainfall shocks, on farm production and on human capital investment like education and health.

Second, research that proposes structural estimates of the income elasticity of school enrolment in low and middle income countries. Some contributions to the second group use, as this paper does, economic shocks as an exogenous variation in income to produce such estimates.

Jacoby (1994) was one of the first who empirically showed that income shocks can have a notable impact on school attendance in poor settings. He emphasized that this effect stemmed mainly from those households which were credit constrained. Jacoby and Skoufias (1997) focused in particular on the impact of seasonal fluctuations in the income of agrarian households. Using panel data from India, the authors found that small farm households were inadequately insured ex ante, and, hence, unanticipated income shocks significantly affected children's school attendance. They also found that households, again in particular smaller farm households, faced serious credit market constraints, sometimes combined with limited storage opportunities, which again had adverse impacts on children's school attendance. Kazianga (2005) used similar panel data for six villages in rural Burkina Faso, the country on which this paper also focuses. He showed that for households without any access to insurance the frequency of income shocks, as measured by the predicted income variance, reduced educational investments in boys and, in particular, in girls. Jensen (2000) showed that in Côte d'Ivoire rainfall shocks affected adversely 
investments in children's health and education. He found, at least in the short term, large effects with school enrolment rates declining by between one-third and one-half and malnutrition doubling. Yamano et al. (2005) provided similar evidence for Ethiopia.

Beegle et al. (2006) used panel data for Tanzania to examine the extent to which transitory income shocks led to increases in child labor and whether household's asset holdings mitigated the effects of these shocks. They found that crop shocks led to a significant increase in the level of child labor, but that households with assets were able to offset at least a large part of that shock. Richer households tended to prefer to use their assets as collateral against credit, whereas poorer households tended to prefer to use them as a buffer. However, school enrolment decreased less than expected because many children were able to combine school and work. Kruger (2007), in turn, examined positive shocks, namely increases in county-level value of coffee production in Brazil. She shows, interestingly, that these shocks led to more work among middle-income boys and girls, poorer children were withdrawn from school, while richer children were not affected. Hence, this study highlighted the potential importance of substitution effects in periods of economic growth. In such periods the opportunity cost of schooling rises and in consequence education may be adversely affected. Maccini and Yang (2009) focused on the long run effects of such shocks. They examined the effect of weather conditions around the time of birth on the health, education, and socioeconomic outcomes of Indonesian adults. They showed that higher early-life rainfall had large positive effects on education, health and asset holdings of women, but not of men.

All these studies above, excepting Kruger (2007), show convincingly that the level and variance of household income matter for children's human capital investments if households have only limited insurance and limited possibilities to smooth their consumption through credit and savings. However, these studies usually do not attempt to provide a structural estimate of the income elasticity of enrolment, and, in particular, to disentangle the effect of income from family background and parental education. Yet, knowing this elasticity is important when designing policy interventions. Behrman and Wolfe $(1984,1987)$ undertook this separation using sibling data for Nicaragua. They showed that the impact of parental education is strongly reduced once family fixed effects are introduced. They did not find an effect of various measures of parental income on children's schooling. Glewwe and Jacoby (2004) examined the relationship between consumption expenditure, which was used as a proxy for household wealth, and the demand for education using panel data for Vietnam. They in turn found a positive and significant relationship between changes in wealth and changes in secondary school enrolment. This effect is shown to be robust to the inclusion of locality-specific factors such as changes in education returns and the supply and quality of schools, and for the opportunity costs of schooling. Deininger (2003) analyzed the impact of a program aimed at eliminating the cost of primary education in Uganda. He concluded that the program led to a strong increase in enrolment, showing that direct costs to schooling constituted a significant obstacle to school attendance, and that as long as such costs are high, parental income is an important determinant of children's enrolment. 
Other studies relied on natural experiments, as this study will do. Rucci (2004) looked at changes in enrolment rates during the Argentinean crisis and instruments household income by the lagged Brazilian Real-US Dollar exchange rate. She also found the IV estimate, depending on age and gender of the child, to be two to seven times larger than the OLS estimate. Cogneau and Jedwab (2008) took cocoa price shocks in Côte d'Ivoire as an instrument for income and explored the difference in investments in children's education and health in families of cocoa and food crop farmers. Regarding the effects on education, they also found strong income effects.

This paper contributes in two ways to the literature discussed above. First, it provides further evidence that unanticipated transitory shocks to (real) household income have an immediate effect on children's school enrolment, suggesting that other risk-coping instruments are insufficient. Second, it provides a relatively accurate estimate of the causal impact of household income on children's school enrolment in a very poor rural African setting.

\section{Background}

\subsection{Agricultural production and prices}

Burkina Faso is one of the poorest countries in the world. GDP per capita is estimated at only PPP US\$1,213 and according to the Human Development Index (HDI), the country was ranked 177 th out of 182 countries (UNDP, 2009). The bad performance in terms of the HDI is in particular caused by a very low education index. The country is landlocked in the middle of West-Africa and has a population of roughly 13.4 million. The country depends highly on cotton exports, which account for almost 60 percent of total export earnings, as well as on international aid. More than 80 percent of the Burkinabè population lives in rural areas working predominantly in the agricultural sector, which suffers from very limited rainfall and recurrent severe droughts.

Figure 1 shows that as a result of the severe drought in 1997/98 total production of the three main food crops - sorghum, millet and maize - decreased by almost 20 percent. Although the production of maize increased during that period, given its relative low weight in food consumption, maize production could not compensate for the decline in millet and sorghum production. These food crops account in normal times for about 30 percent of total expenditure (including imputed expenditures for own production) for rural households in the poorest quintile of the expenditure distribution. At the same time cotton production increased by more than 80 percent.

$$
\text { [insert Figure 1] }
$$

Figure 2 shows that the prices of cereals rose tremendously between 1994 and 1998. This rise was caused first of all by the production shortage following the drought. But even before that drought prices tended to rise due to rising input prices after the devaluation of the CFA Franc in 1994 and a lack of productivity increases in cereal production, accompanied by continuous high 
population growth. In some years a high demand for cereals from neighboring countries also put pressure on prices in Burkina Faso.

$$
\text { [insert Figure 2] }
$$

Following the devaluation and the favorable development of the world market price of cotton, the Burkinabè cotton marketing board 'Société Burkinabè des fibres textiles' (SOFITEX), which was in place at that time ${ }^{3}$ increased the producer price in several steps. Despite the fact that the costs of inputs also increased, as most of them have to be imported, the rise in producer prices still provided enough incentives to expand cotton production, mainly by the expansion of land allocated to cotton production (Grimm and Günther, 2007a).

After 1998 cereal prices fell back to lower levels, before rising again due to a second drought in 2000/01. The immediate consequences of the second drought are difficult to assess, since household survey data only exists for 1994, 1998 and 2003. As Figure 1 shows, in 2002 cereal production had already recovered and prices for millet and sorghum in particular were significantly lower in 2002 than in 1998.

Obviously such price hikes in food staples can always have two types of consequences. Households who are net producers of these cereals will benefit, i.e. the income effect will more than outweigh the price effect. Households who are net consumers will, in turn, suffer real income losses. Household survey data for 1998 shows that in rural areas 94 percent of all households produced cereals, but only 15 percent sold any on the market. In contrast, the share of purchased cereals in total cereal consumption was on average 49 percent (Grimm and Günther, 2007a). Thus, in rural Burkina Faso most of the households are losers of such price increases, in particular in periods of harvest failures since this obviously means also lower output. ${ }^{4}$

It is important to emphasize that the cereal prices shown in Figure 2 are consumer and not producer prices. The latter are often much lower given the negotiation power of traders and the information asymmetries prevailing between traders and farmers. Also, farmers do often not have appropriate storage facilities and thus are forced to sell their cereals directly after the harvest, resulting in a fall in prices. Traders on the other hand, are able to store cereals, to speculate in the market and to drive the price up by allocating their supply over the whole year.

\subsection{Schooling system}

In Burkina Faso basic education includes pre-school classes for a maximum duration of three years; normally children from three to six years of age can attend. Primary school starts officially at the age of seven and lasts in total six years. Secondary school is comprised of two types of curricula: the general

\footnotetext{
${ }^{3}$ At that time SOFITEX was the only importer of agricultural inputs such as fertilizer and pesticides and the only buyer of cotton. For a detailed description of the sector, see e.g. Kaminski (2007).

${ }^{4}$ See Reardon, Matlon and Delgado (1988) for similar evidence on Burkina Faso
} 
curriculum and a technical curriculum. Lower secondary education lasts four years. General higher secondary education lasts three years. Technical higher secondary education can be three years (long) or two years (short). Successful completion of general higher secondary education enables entry into tertiary education.

In principle school is compulsory for the age group six to sixteen. But the law explicitly states that this is conditional on the availability of schools, teaching material and teachers. De facto, many children never go to school or if they do, only for a few years, particularly in rural areas. In addition, school entry is often delayed, repetition rates are high and there is still an important, although decreasing, gender gap in rural areas.

The schooling system is comprised of public and private schools. Private schools charge fees. Public schools are always free of charge and parents only have to buy text books, school supplies and a school uniform. Until 2007 it was also custom that parents paid 1,000 CFA Francs (about 10 PPP US\$) each year into the parents' association. However, this was abolished in 2007. Today, public and private schools receive text books from the government.

\section{Theoretical considerations}

It is assumed that the typical rural agricultural household in Burkian Faso is liquidity constrained, given the lack of insurance and limited possibilities to smooth consumption through credit and savings. Empirical evidence for Burkina Faso supporting this assumption has been provided by Kazianga and Udry (2006) and Reardon et al. (1996). It is further assumed that children's future earnings are positively related to their educational investments and influence positively current parental utility.

In such a setting, and if farmers are net consumers of food crops, a rise in food crop prices should have a negative impact on real income and reduce educational investment. This may be partly offset by the fact that direct schooling costs (e.g. expenses for textbooks, school supplies, uniforms and transport) decline relative to food prices. However, in our case described above this substitution effect should be small relative to the income effect and thus can be neglected. If the wage for child work also goes up, the indirect cost of schooling rises and lowers schooling further, but this also depends on the change in opportunity costs for older children and adults. However, in Burkina Faso, most children, if they work, work on the family farm. Given that the hike in food prices was caused by a serious shortfall of production, it is unlikely that children's productivity on food crop farms, and hence their (implicit) wages, increased. A third potentially relevant channel is the effect of food prices on returns to schooling. Nevertheless, given the temporary nature of the food price shock and given that investments in education are seen as a route to more lucrative employment outside agriculture, this channel does not seem very relevant in the setting of this study.

If, in contrast, households are net producers of food crops, they may have experienced a positive income effect, if the price increase over compensated the 
decline in production. In this case enrolment should have gone up. However, as the analysis of the context above has shown, only very few households in Burkina Faso fall into this category.

But, and more importantly, given the simultaneous boom of cotton prices, the main export crop in Burkina Faso, children in cotton producing households, in turn, should have experienced a smaller depression of real income, given that additional income from cotton production should have mitigated the negative effect on real income that resulted from the hike in food prices. However, rising cotton prices, which in this case where also accompanied by rising production quantities, should have raised the opportunity cost of children's time too and therefore, may have, in turn, lowered the schooling of these children. The effect of cotton prices and cotton production on the long run returns to schooling are again supposed to be negligible.

Hence, linking these theoretical considerations to the context described above, in particular the fact that between 1994 and 1998 food crop farmers and cotton farmers experienced a substantially different development of (real) household income, one would expect that the loss in purchasing power for food crop farmers would have led to a substantial decline in school enrolment of children in these households. In contrast, school enrolment of children living in cotton households should have been affected less, given the boom in that sector. The latter is of course only true as long as the income effect is higher than the substitution effect, i.e. children living in cotton households were not put to work more often given the possibly increased opportunity cost of schooling. This latter issue will be addressed below too.

\section{Data}

I use three nationwide representative household survey data sets, so-called Enquête Prioritaires (EP), undertaken in 1994 (EP I), 1998 (EP II) and 2003 (EP III) covering around 8,500 households in each year. These surveys were conducted by the Institut National de la Statistique et de la Démographie (INSD) with technical and financial support by the World Bank. These surveys contain relatively detailed information on households' socio-demographic characteristics, education, employment, agricultural and non-agricultural activities as well as consumption, income and some assets. A detailed description of these data sets can be found in Grimm and Günther (2007b).

In these surveys households are defined as a group of people that live together, share their meals together and acknowledge the authority of one person, called the household head. Individuals are only counted as household members if during the past 12 months they spent at least 6 months in the household. ${ }^{5}$ Visitors and personnel are not counted as household members in the analysis.

Information on school enrolment is provided for all children older than five years. However, it is important to note that in the 2003 survey the question on

\footnotetext{
${ }^{5}$ However, there are three exceptions: The household head is always considered as a household member as are new-born children and women that joined the household through marriage. All others are considered as visitors.
} 
school enrolment was formulated differently than in 1994 and 1998. Whereas in 1994 and 1998 the survey asked whether 'a person was enrolled in school in 1994/1995 and 1997/98 respectively', i.e. in the current school year, the 2003 survey asked whether 'a person was currently enrolled in school'. Given that about a third of all households were interviewed in July, i.e. during the school holidays it may be the case that many reported 'no enrolment although the child was still enrolled before the summer holidays; and children that were supposed to start after the holidays were not yet reported as enrolled. ${ }^{6}$ Hence, the analysis of the causal effect of income on enrolment will only rely on the surveys undertaken in 1994 and 1998. All surveys also asked all individuals who ever attended school for the highest education level ever achieved. But the surveys did not ask about the data of school drop outs. For children ten years and older, the surveys also inform whether a child worked, e.g. on the household's farm or non-farm business or outside the household.

Given the usual low quality of income data in poor rural settings, I use household expenditure per capita as a measure of households' income. Household expenditures include all expenditures by the household for all household members, including auto-consumption and received transfers in-kind both evaluated at market prices as well as transfers in cash and in-kind given to other households. Hence, it is a measure of disposable resources. The expenditure module of the questionnaire has different sections in which subsequently expenditures for food and non-food items including expenditure for health, education and transfers are reported. The recall period for food-times is either 15 or 30 days, for all other items it is 6 or 12 months. All expenditures are scaled to yearly expenditures. Expenditures were deflated over time and space using temporal and regional price deflators. Given the changes in relative prices in the second half of the nineties mentioned above, e.g. the substantial rise in cereal prices and the significant differences in consumption habits across the income distribution, I use decile-specific price indices to deflate expenditures over time. Using only the general consumer price index would over-estimate the living standard of the poor. This is shown in detail in Grimm and Günther (2007b, 2007c).

All those farmers who produced at least one $\mathrm{kg}$ of cotton in the survey year are coded as cotton farmers. Most of these farmers also produce some food crops. All other farmers are coded as food crop farmers. However, I will test the sensitivity of that definition to alternative assumptions. It should be noted that cotton farmers are, similarly to food crop farmers, usually small family farms with in most cases not more than a few hectares of land.

In what follows I restrict my sample to two relatively homogenous and well defined groups, namely food crop farmers and cotton farmers, and exclude pure livestock farmers and all other socio-economic groups. I only consider rural areas and limit the sample to households in the South and South-West of the country (regions of Hauts-Bassins, Sud-Ouest, Cascades, and the southern parts

\footnotetext{
${ }^{6}$ Indeed, comparing the survey information with official data on gross and net enrolment rates provided by the Ministère de l'Enseignement de Base et de l'Alphabétisataion for the school years 1997/98 and 2002/03 I find that the 2003 survey underestimates enrolment, in particular in provinces with a high share of cotton farmers.
} 
of Boucle du Mouhoun, Centre Ouest, Centre Sud, Centre Est and Est), excluding the relatively dry tropical savannah in the north. ${ }^{7}$ Applying those criteria reduces the sample to in total 6,610 households for all three years together. Although one can find cotton cultivation almost everywhere in the country, in this area more than 80 percent of the total cotton exports are produced.

\section{Empirical Evidence}

\subsection{Income}

Table 1 shows the development of real household expenditure per capita. For the reasons given above, I focus on the period 1994 to 1998. The shock on cereal output and the resulting food price inflation reducing the purchasing power of households are clearly visible. On average expenditures decreased by almost 24 percent in real terms. Comparing cotton farmers with food crop farmers, one can state that both groups had a similar living standard in 1994. Then, between 1994 and 1998 real expenditures of food crop farmers decreased by almost 30 percent, whereas the real expenditure of cotton farmers decreased by 'only' 16 percent. Between 1998 and 2003, both groups again saw a very similar growth rate of about 37 percent over the whole period lifting food crop farmers and cotton farmers to expenditure levels of CFA Francs 59,400 and CFA Francs 71,000 respectively (not shown in Table).

[insert Table 1]

\subsection{School enrolment}

Enrolment rates for boys and girls six to thirteen years old (regular age of attending primary school) in 1994 and 1998 for both types of farmers are shown in Table 1. While in 1994 there are no differences in enrolment rates between boys and girls in cotton farmer and food crop farmer households, in 1998 enrolment rates were significantly lower in the latter compared to the former. The development over time is even more distinct for the age group ten to thirteen years old, since for this group enrollment in cotton farmer households even increased, however, starting from a lower level. This in turn means that the observed decline for the whole group of children in cotton households is mainly driven by delayed entry of six-year old children or drop outs during the first four years. School enrolment is further analyzed in Table 2, now including the 2003 data set. Column (1) shows the temporal pattern of enrolment rates of children living either in food crop or cotton farmer households. This pattern is obtained by regressing enrolment status on cotton and year dummies and

\footnotetext{
${ }^{7}$ The narrow spatial and socio-economic definition of both groups to be compared ensures that this comparison is not affected by other shocks which might have occurred during that time. For instance, livestock farmers faced a different development in their production and in prices than pure food crop farmers. Urban households have suffered more under the price rise of imported food items than have rural households. Moreover, in the North there are only few cotton farmers, which would make a comparison with other farmers in this area somewhat fragile.
} 
cotton and year interaction terms. The regression also controls for age (coefficients not presented), relationship to the household head i.e. child of the head or not (coefficient not presented), gender and the interaction of gender, cotton and year effects.

[insert Table 2]

The results suggest that children in cotton households have, on average, the same probability to be enrolled as children in food crop households. The cotton dummy is not statistically significant. In 1998 children as a whole were significantly less likely to be enrolled than in 1994 and 2003. In that year the enrolment probability was on average 8.1 percent lower than in the two other years. The decline in enrolment thus coincides with the drought-induced crisis. There is no evidence, that for instance other shocks that would have depressed returns to education in the public or private formal sector led to this decline. ${ }^{8}$ However, for children in cotton households this effect was on average much lower. The corresponding coefficient of the cotton-year interaction indicates that in 1998 these children had a probability to be enrolled which was higher by 6.4 percent. This interaction effect is insignificant in $2003 .^{9}$ However, as discussed above the 2003 data has to be used with caution, given the slightly different question on school enrolment, which probably implies an underestimation of enrolment in that year.

The other control variables indicate, as one can expect in the given context, that boys have, in general, a higher probability to be enrolled in school than girls. But it is interesting to see that in 1998 girls' enrolment was less affected than boys' enrolment. This could be explained by the higher opportunity costs for the schooling for boys. Below I will analyze this issue in more detail. However, it should already be noted that the interaction term of 'being a boy' and 'being a child of a cotton household' is insignificant. That suggests that in this age group boys in cotton households are on average not more likely to be enrolled than boys in food crop households.

\subsection{Education expenditures}

Columns (2) and (3) in Table 2 show the development over time of schooling expenditures per household member and per child. These direct schooling costs account on average for about 2.5 percent of the total household budget. The results in Table 2 are consistent with the impact observed for school enrolment: a general decline in schooling expenditures in 1998, but a positive and highly significant impact of the cotton-year interaction term in 1998. Thus in 1998 cotton households reduced their schooling expenditures significantly less than food crop farmers. The linear year effect in combination with the interaction effect even suggest that there was no reduction at all for children in cotton

\footnotetext{
${ }^{8}$ Public and private formal employment and wages were relatively stable during that period, see Grimm and Günther (2007a).

${ }^{9}$ The results are qualitatively the same, if a probit model is estimated.
} 
households. The cotton dummy is insignificant in column (2) and weakly significant in column (3), i.e. in normal times, there is hardly any difference in schooling expenditures between food crop and cotton farmers.

\subsection{Child work}

Table 1 shows that child work is relatively widespread among children ten to thirteen years old, in 1994 slightly more often among children in cotton households compared to children in food crop households. In the study area on average more than 70 percent of all children do some work without attending school and another five to ten percent combine school and work. Children who work usually help on the family farm (more than 90 percent of all cases). Work outside the household is rather an exception. Between 1994 and 1998, child work declined for boys and girls in cotton households and increased in food crop households. The associated double-difference is highly significant. Table 3 shows the results of a linear probability model, where the dependant variable takes the value one if the child was reported to work during the past seven days. Given that some children (about four percent) work and go to school, I estimate two models; one where 'school and work' is counted as work (col. (2)) and one where 'school and work' is counted as school (col. (3)). The surveys do not contain any information on working hours. Children were only asked what the principal activity was; but for those working and attending school it was not asked whether one or the other activity was the main activity. Information on activities other than schooling is available for children ten years and older. Hence, I include the age group ten to thirteen in the regression. This is different to the age group considered in Table 2, but it still refers to children in primary school. I use the same control variables as in Table 2 . To facilitate comparisons, column 1 in Table 3 re-estimates the enrollment model of Table 2 for the age group ten to thirteen years old.

\section{[insert Table 3]}

The regression results confirm that in this age group children in cotton households worked more often than children in food crop households. Moreover, in 1998 all children were more likely to work than to be at school (plus 13 to 17 percent). However, the cotton-time interaction shows that in 1998 children in cotton households were relatively to the other years much less likely than children in food crop households to work. This effect is highly significant and fully offsets for that group the year effect. In 2003 these differential effects between children in cotton and food crop households disappeared again. Regarding the gender differences, boys in that age group had a slightly lower probability than girls to work, in both years 1998 and 2003 and relative to 1994. The difference between the coefficient estimated in col. (2) and col. (3) suggest that boys more frequently combined school and work. The findings in Table 3 in conjunction with those in Tables 1 and 2 suggest that in 1998 both, boys and girls in food crop households, were affected by lower enrolment, however, whereas for boys the effect seems mainly to have happened via delayed entry, 
for girls it seems mainly to have happened via a withdraw from school at older ages and an increase of their participation in farm and house work.

\subsection{First conclusions}

All results above suggest that food crop farmers were significantly hit by the drought and the rise in food prices and that they responded to the associated loss in purchasing power by reducing children's school enrolment and letting them work more often. It is also important to highlight that child work among cotton farmers did not increase relative to child work among food crop farmers despite the boom in the cotton sector.

\subsection{Income elasticity of school enrolment}

\subsubsection{Identification strategy}

The simultaneous shocks induced by the cereal crises and the cotton boom caused a variation in income over time and household groups, which can help to identify the causal impact of household income on children's schooling. I rely on the period 1994 to 1998 for identification since this is the period in which both shocks occurred. In order to test the symmetry of negative and positive shocks, it would in principle also be interesting to analyze the income elasticity over the period 1998 to 2003. However, two reasons prevent doing this. First, as mentioned above, information on school enrolment in 2003 is potentially biased. Second, the positive income shock after 1998 is almost identical among cotton and food crop farmers. Both groups experienced an growth in household expenditure per capita of about 36 percent. Hence, there is no differential in growth rates that could be used for identification.

I use expenditure as a proxy for income, thus ignoring the role of savings. This implies that, if consumption smoothing or insurance (or both) take place, for which again there is only weak evidence in Burkina Faso, the relationship which is analyzed is rather between permanent or average income and schooling than between current income and schooling.

A standard OLS model of the income effect can be written as follows:

$$
S_{i j t}=\alpha+\beta \text { Cotton }_{i j t}+\gamma Y \operatorname{ear}_{t}+\delta \ln \operatorname{Inc}_{i j t}+\sum_{k=7}^{13} \zeta_{k} A g e_{i j t k}+X_{i j t}^{\prime} \eta+\theta_{j}+\varepsilon_{i j t} .
$$

Enrolment, $S_{i j t}$, is a binary variable taking the value one, if the child $i$, living

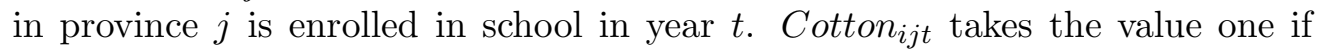

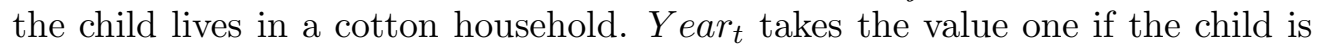
observed in 1998 (and zero if observed in 1994). The variable $\ln I n c_{i j t}$ stands for the logarithm of household expenditures. I do not express expenditures in per capita terms, because this could lead to identification problems in an enrolment equation, given that fertility and educational investments might be jointly determined and have the same unobservable determinants. However, if household composition responds to income shocks, income may have an omitted variable bias. Whether this is an issue will be examined below. The coefficient 
$\delta$ measures the income elasticity of school enrolment. Given that the unobservable characteristics of children living in the same household are likely to be correlated, I use robust standard errors for inference.

$A g e_{i j t k}$ are age-specific dummies for each age group between seven and thirteen years with the age of six being the reference group. $X_{i j t}^{\prime}$ is a vector of other household and individual control variables, including parental education, position of the child in the household, and variables reflecting the composition of the household. $\theta_{j}$ are province fixed effects which account for differences in the rate of return to education and school supply and quality. Obviously, I have to assume that education supply and the prices relevant for enrolment decisions did not change in a different way for both groups of farmers. Unfortunately data on the number and placement of schools is for this period not publicly available and hence this issue cannot be further explored. ${ }^{10}$

I do also not account for direct or indirect schooling costs. Precise information about direct schooling costs are not published, but the substitution effect stemming from the relative price change between food and school related items can be assumed to be very small compared to the income effect. The effect of indirect costs seems also not very important, because as Table 3 showed, children in cotton farming households have worked much less in 1998 compared to 1994, not more. Moreover, the survey provides only very limited information about earnings of children in the concerned age group.

The OLS estimate of the income effect above is obviously subject to a number of biases. In principle, the most important ones are the simultaneity bias and the omitted variables bias. The simultaneity bias arises if enrolment is a substitute for child work and thus has a negative impact on household income. Simultaneity would bias $\delta$ downward. Omitted variable bias can stem from a number of causes and can introduce a downward or upward bias. For instance, unobserved parental abilities may have a positive impact on income and make it more likely that parents send their children to school. This would upward bias the income effect. Household income could also be correlated with better opportunities for children to get a job which requires a certain level of education. This would increase the expected returns from education and thus again bias the income effect upward.

A further downward bias of the income effect may result from measurement error in the income variable. Although for most industrialized countries that bias should be relatively small, in the case of a poor agrarian country that bias can be very important and may even dominate the two other biases. However, it is not straightforward to get a rough estimate to what extent measurement error could bias the income effect. Validation surveys are frequently conducted in industrialized countries (see e.g., Bound, Brown and Mathiowetz, 2001), but do not exist for the Sub-Saharan African context.

In order to obtain an unbiased estimate of the income effect on school enrolment, I rely on the distinct development of incomes of food crop and cotton

\footnotetext{
${ }^{10}$ In a personal interview, staff from the Ministère de l'Enseignement de Base et de l'Alphabétisataion stated that there were at least no systematic differences in school construction between villages that are dominated by cotton farmers and villages that are dominated by food crop farmers.
} 
farmers in the period 1994 to 1998. I use a 2SLS estimator and instrument income with the interaction effect 'being a child in a cotton household in 1998' conditional on 'being in a cotton household' and the time effect. Using this instrumentation strategy, Equation (1) can be rewritten as:

$$
S_{i j t}=\alpha+\beta \text { Cotton }_{i j t}+\gamma Y \text { ear }_{t}+\delta \ln \hat{I} n c_{i j t}+\sum_{k=7}^{13} \zeta_{k} A g e_{i j t k}+X_{i j t}^{\prime} \eta+\theta_{j}+\varepsilon_{i j t}
$$

where the first stage equation is given by

$$
\begin{gathered}
\ln \text { Inc }_{i j t}=\vartheta+\text { Cotton }_{i j t}+\kappa \text { Year }_{t}+\lambda\left(\text { Year }_{t} \times \text { Cotton }_{i j t}\right)+ \\
\sum_{k=7}^{13} \mu_{k} \text { Age }_{i j t k}+X_{i j t}^{\prime} \nu+\xi_{j}+\omega_{i j t} .
\end{gathered}
$$

Given the differences in enrolment patterns for boys and girls, I run the regression separately for boys and girls. ${ }^{11}$

Obviously a number of assumptions have to be verified to ensure that this instrumentation is valid and yields an unbiased income effect. First, the instrument needs to be relevant. That this is the case, was shown in Table 1. Whereas food crop farmers and cotton farmers had a similar living standard in 1994, cotton farmers were significantly richer than food crop farmers in 1998. After 1998, incomes of both groups followed again a similar dynamic. Second, I assume that being a child in a cotton household in that particular year 1998 is uncorrelated with the error term in the main equation of (2), i.e. the instrument does not have any direct impact on school enrolment other than its impact through income, once the linear effect of time and 'being a child in a cotton household' is controlled for. Note that there is no evidence that children in cotton households worked more often following the cotton boom (cf. Table 3 ). Third, I assume that children in cotton households and food crop households would have known the same change in school enrolment over time in the absence of the shocks on income. Table 2 shows at least that the cotton dummy is insignificant. Here it should also be noted, that during that time, there was a very homogenous and stable education supply within and even across provinces (although I control for province fixed effects). Thus, there is no evidence that villages that were dominated by cotton farmers had more or better schools than villages dominated by food crop farmers. During that time there was also no larger-scale school construction program in place. The expansion of education supply started later, in the early 2000s, when the first 'Poverty Reduction Strategy' was implemented.

Table 4 shows the differences over time in the observable education-related variables for all survey years and both types of children, those living in cotton households and those living in food crop households. The table also shows

\footnotetext{
${ }^{11}$ The model could also be estimated using a probit specification. However, for interpretational convenience and to avoid inconsistent estimates given that fixed effects are included, I use the linear specification.
} 
the differences in the changes over time between both groups. Larger differences in the changes over time only arise in variables that track changes in the household composition and the age of the household head. The latter difference can however be explained by the difference of the timing of the interviews in each survey year. Regarding the household composition it can be noted that the average share of children that are children of the household head follows a different trend over time for both groups. Whereas for children in food crop households this share increases, it decreases for children in cotton households. Given the cross-sectional nature of the data, it is not possible to find out what exactly drives this structural change. It could imply that some children that lived originally in food crop households, but were not children of the household head were fostered by cotton households when incomes started to diverge between both groups. This would also be consistent with the observed changes of household size over time; which slightly increases for cotton farmers $(+0.25)$ and slightly decreases for food crop farmers (-0.3). Akresh (2005) has shown that, for instance, households in the Bazega province - which is outside the area which is covered by this study - rely on child fostering to mitigate shocks. He also showed (Akresh, 2004) that the foster children are equally likely as their host siblings to be enrolled and they are slightly more likely to be enrolled than their biological siblings, but both the foster children and their biological siblings experience increased enrolment after the fostering exchange. If that would also be the case in the context analyzed here, it would mean that I underestimate the income elasticity of school enrolment. However, the bias should be moderate, since household size in cotton households increases only slightly and the share of children in the relevant age group (6-13) increases by only 1.2 percentage points in cotton households and does even not decline (but rather increase) in food crop households. All these variables will be included as control variables in the regression. I will also run regressions where I control for livestock and non-farm business ownership. However, both variables are not very precisely measured and may in addition lead to further endogeneity problems. Hence I will only briefly report the results but not include them in the preferred and presented regressions.

[insert Table 4]

Finally the instrumentation would pose complications if the cotton boom provided an incentive to food crop farmers to switch to cotton production. If those switching households differed in unobservable characteristics correlated with their decisions regarding children's school enrolment, the estimated income effect could again be biased. Between 1994 and 1998 the share of cotton households, i.e. households which produced at least $1 \mathrm{~kg}$ of cotton, increased by 13 percentage points from 21 percent to 34 percent. ${ }^{12}$ To account for the potential bias in the estimates due to switching households, I undertake below a number of robustness checks.

\footnotetext{
${ }^{12}$ Between 1998 to 2003 this share increased by another 4.9 percentage points.
} 


\subsubsection{Results}

Table 5 shows the estimation results. For boys the OLS estimate in column (1) suggests that a ten percent increase in household income leads to an increase in the probability of being enrolled of 0.73 percent $(p>0.001)$, controlling for age, year, household type and province fixed effects. For girls (column (5)) this elasticity is only 0.16 percent and not significantly different from zero $(p=0.17)$. The cotton dummy is insignificant, supporting the identification strategy for the income effect below. The 1998 year dummy indicates that in 1998 enrolment rates were on average lower by ten percentage points for boys and five percentage points for girls. If income is instrumented (cols. (2) and (6)) the income effect rises substantially. For boys the income effect increases to 0.22 , suggesting that an increase of income by ten percent increases the probability of enrolment, on average, by 2.2 percent: that is roughly three times the effect suggested by the OLS regression. The $F$-statistic in the corresponding first-stage regression is far above the critical value of ten, indicating again that the used instrument is relevant (Stock and Yogo, 2002). For girls the instrumented income effect is even higher (0.33) than for boys and again, the $F$-statistic indicates that the instrument is relevant. The cotton dummy is still insignificant. The higher elasticity for girls must be driven in particular by enrolment changes of girls in the age group ten to thirteen, since in younger age groups enrolment declined more for boys.

[insert Table 5]

In columns (3), (4), (7) and (8) I introduce additional regressors, in particular parental education and household composition, including the position of the child in the household relative to the household head. For boys the OLS effect slightly declines, whereas the instrumented effect increases to 0.25 . The $F$-statistic of the first stage regression further increases; thus is well beyond the critical threshold. For girls the instrumented income effect declines to 0.30, thus comes closer to the effect estimated for boys. Parental education has (or more precisely education of the household head and his/her spouse) a significant positive impact on enrolment rates. Interestingly the household's head education is more important for girls than for boys. The opposite is true for the education of the spouse of the household head. Here the effect is larger for boys. Whereas for girls the parental education effect does not differ a lot between the OLS and IV estimates, the effects decline in the case of boys, suggesting that a simple OLS estimation attributes parts of the income effect to the parental education effect. For both, boys and girls, the comparison of the OLS income effect with the instrumented income effect suggests that the simultaneity bias and the measurement error bias probably dominate, provided that the omitted variable bias would rather upward than downward bias the OLS effect.

I also estimated the models in columns (4) and (8) by adding business ownership and livestock ownership to the set of controls (results not presented in Table 5), although as discussed above, their inclusion is not without problems, mainly because of potential endogeneity issues. However, the estimated income effects are for both, boys and girls, robust to the inclusion of these controls. 
Livestock ownership has a negative effect on boys' enrolment, probably due to the fact that boys are often involved in herding of cattle. Ownership of a private non-farm business also has a positive impact. This can be due either to a wealth effect or to a returns on education effect. If education is particularly valuable for the 'management' of a non-farm business, parents owning such a business may invest more in the education of their children. For girls, both variables are insignificant.

I also added the square root of household size as a control variable (results not presented in Table 5) to account for the fact that households may respond to income shocks by adjusting their household size. Indeed, if household size is controlled, the instrumented income effect increases further (by about 0.05 points), showing that income and household size are positively correlated. As I discussed above, it is possible that some cotton households fostered children from food crop households which then led to lower income growth in per capita terms than in absolute terms. This can also explain the lower $F$-statistic, though still above ten for boys and girls.

Before I present further robustness checks, it is important to discuss the local character of the IV estimate. As pointed out by Angrist and Imbens (1995), the parameter that is obtained via instrumentation captures a weighted average of causal responses to a unit change in treatment, for those whose treatment status is affected by the instrument. Inspection of the cumulative income distribution functions for cotton and food crop farmers in 1994 and 1998 and their double difference (by percentile) reveal that the double difference is positive along the entire income distribution (i.e. cotton farmers experienced a smaller decline in real income than food crop farmers). However, this double difference is slightly more pronounced in the bottom 40 percent of the distribution. This implies that the instrumented income effect may not be fully representative for the entire income distribution. It may also imply that the increase of the IV effect relative to the OLS effect partly stems from a possibly higher income elasticity of schooling at the bottom of the distribution. However, the variation of the double difference across the distribution is relatively limited suggesting that the IV estimate constitutes a fairly representative income effect.

\subsubsection{Robustness checks}

If households which started to grow cotton after 1994 differed in their unobservable characteristics correlated with their decisions regarding children's school enrolment, the estimated income effect could be biased. In order to test the robustness of the estimates in Table 5, with respect to this specific issue, I reestimate the model under various alternative assumptions. Table 6 shows the results. In all these tests there is generally little case for weak instruments, except in a few instances.

First, I introduce in Equation (2) an interaction term between 'being a cotton farmer in 1998' and 'having not been a cotton farmer the season before' (i.e. in 1996/97) ${ }^{13}$ For boys, the income effects for both estimations, OLS and

\footnotetext{
${ }^{13}$ In absence of panel data, I cannot refer to the the season 1993/94.
} 
IV, remain more or less unchanged. The $F$-statistic of the first-stage regression of the IV estimation goes even further up, showing that, once controlled for the 'newcomer status', 'being a cotton farmer in 1998' is even more strongly correlated with income. For girls, the interaction term is significantly positive. The instrumented income effect is slightly lower but remains significant at ten percent. In the next row, I merge all households who joined the cotton sector after 1997 with food crop farmers. This reallocates about seven percent of all children. The instrumented income effect for boys is close to the estimate in Table 5 and for girls the effect decreases and is now similar to the effect for boys.

\section{[insert Table 6]}

Another way of dealing with the problem of households which switched to cotton production is to merge those households which produced only relatively small quantities of cotton with food crop farmers. The assumption is that new cotton farmers allocate on average less land to cotton than well-experienced cotton farmers. ${ }^{14}$ Of course, the risk is that this systematically excludes cotton farmers who do not have much land and are thus relatively poor. I use two alternative cut-off points. The first eliminates all farmers who produced less than $50 \mathrm{~kg}$ of cotton, which reallocates about 3.5 percent of the cotton farmers from the sample. The second cut-off point reallocates all farmers who produced less than $250 \mathrm{~kg}$ of cotton, which reallocates about 8.5 percent of the cotton farmers to food crop households. ${ }^{15}$ With the first cut-off point the results for boys lead to a lower IV estimate. For girls the relevant first-stage $F$-statistic gets close to ten and the income effect turns out be insignificant. Using the second cut-off point, the instrumentation also looses its power for boys and the instrumented income effect increases substantially. However, the second cut-off point is really far beyond the upper boundary and obviously reallocates not only 'newcomers', but poor cotton farmers as well. I did a similar robustness check by reallocating households based on their share of their total agricultural income from cotton (results not presented in Table 6). Again I used two cut-off points, the first at ten percent (reallocating about four percent of all cotton households) and the second at 50 percent (reallocating about ten percent). The IV estimates of the income effect increase for boys and girls, more so when the higher cut-off point is used. With the 50 percent cut-off point the income elasticity of enrolment is 0.22 for boys and 0.29 for girls. Both effects are significant.

I also tested whether all results hold if instead of reallocating those households which probably recently joined, I remove them from the group of cotton farmers. The results were very similar. All effects hold, except for the variant where those households are defined as 'joiners', which earned less than $50 \%$ of

\footnotetext{
${ }^{14}$ Note that the size of the plots allocated to cotton and cultivated land size in general is not available in the surveys.

${ }^{15}$ Note that quantities can only be computed approximately since respondents had the possibility to provide the quantities in terms of the number of baskets, sacks etc. This information was then converted into $\mathrm{kg}$.
} 
their agricultural income from cotton production. This again is a very high threshold. These robustness checks suggest that activity changes do not drive the results and do not lead to a substantial bias in my estimates.

The estimates obtained in this paper are also fully consistent with other studies that have tried to identify the causal impact of income on school enrolment. Cogneau and Jedwab (2008) used a negative shock on cocoa prices for identification and estimated that in Côte d'Ivoire a 10 percent decline in income led to a 3.2 percentage points decline in school enrolment. Using data for Conakry, the capital of Guinea, another West-African country, Glick and Sahn (2000) estimated the income elasticity of school enrolment for girls in the age group 10 to 18 at 0.257 , or a 2.6 percentage points change in enrolment per 10 percent change in income. However, for boys they only find an insignificant income effect. The analysis controls for household random effects, but does not account for reverse causality and measurement error, which may explain the insignificant effect for boys. Deininger (2003) found for Uganda, using a simple probit framework, an elasticity of 0.12 for the 6 to 12 age group. This is lower than my estimates, but in his paper Deininger (2003) does also not address a potential bias through reverse causality and measurement error, which, again, may explain the lower estimate. Finally, the estimates of this study can be compared with those obtained by Glewwe and Jacoby (2004). Although they study the case of Vietnam, so clearly a different context from West-Africa, they use panel data and deal very carefully with all identification issues. For children in the 10 to 18 age group they find an elasticity of about 0.2 to 0.3 , depending on the chosen specification. This is again very close to the estimates obtained in this study.

\section{Conclusion}

In this paper I analyzed the income elasticity of school enrolment in an African, poor and rural context. I find strong and robust effects. Relying on an instrumental variable strategy for identification, the estimates suggest that a decline in income by ten percent causes a decline in enrolment rates among boys six to thirteen years old by about 2.2 to 2.8 percentage points. This impact is three to four times higher than what a simple OLS regression would imply. For girls I find an elasticity that is slightly higher. It is important to note that the OLS estimate is probably not only downward biased because of a 'simultaneity bias' but also because of 'measurement error bias'. I have shown that these estimates are in line with the few other studies that have tried to identify the causal impact of income on school enrolment in West-Africa. So far, existing evidence comes mostly from developed countries or from Latin-America and South-Asia, and is often based on an analysis of conditional cash transfer programs. Given the conditionality in these latter programs it is generally difficult to derive from them the direct effect of parental income. In addition, it is unlikely that these results can be generalized to the context of Sub-Saharan Africa. Given that this

region has by far the lowest education levels in the world, the results from this paper should be particularly policy relevant. They may of course not apply to 
Sub-Saharan Africa as a whole, but are probably at least transferable to other rural areas in francophone West-Africa: All these countries inherited more or less the same schooling system, rural areas are usually very poor; many households engage in cash crop production, market integration of food crop farmers is rather low and enrolment rates are fare behind the targets specified in the MDGs, in particular for girls.

It is however important to emphasize the local character of the estimates in this paper. They are identified from a negative and probably largely unanticipated shock. Hence, the results may not be transferable to a positive shock or an anticipated permanent shock such as a permanent income transfer. Also they do not fully account for general equilibrium effects. What I show is that income matters for school enrolment, and by how much, if income falls in a context in which households face tight liquidity constraints. The results can thus provide the basis for safety net policies, such as unconditional income transfers in times of recession, but less so for permanent income transfers.

In the presented case the considered shock had a sizable impact, that probably could have been prevented with an appropriate policy response. Between 1994 and 1998 Burkinabè food crop farmers experienced on average a decline of more than 30 percent in their real income. As shown this led to a substantial cut in their spending on education and a drop of more than ten percent in enrolment rates. This corresponds to more than 100,000 children which were not enrolled or were withdrawn from school during that period; many of them probably permanently.

In the coming years substantial resources will be spent on programs to increase school enrolment rates in Sub-Saharan Africa. The results of this study imply that decision-makers should not only focus on the supply side of education, like school construction and the training of teachers, but should also implement measures to strengthen the demand side in times of shocks. Time is pressing. In Burkina Faso for instance, during the world food crisis between June 2007 and June 2008 cereal consumer prices rose again by $110 \%{ }^{16}$

\section{References}

Akresh R. (2004), Adjusting household structure: school enrolment impacts of child fostering in Burkina Faso. Center Discussion Paper No. 897, Economic Growth Center, Yale University.

Akresh R. (2005), Risk, network quality, and family structure: child fostering decisions in Burkina Faso. IZA Discussion Paper No. 1471, IZA Bonn.

Angrist J.D. and G. W. Imbens (1995), Two-Stage Least Squares Estimation of Average Causal Effects in Models with Variable Treatment Intensity. Journal of the American Statistical Association, 90 (430): 431-442.

Baland J.-M. and J.A. Robinson (2000), Is Child Labor Inefficient? Journal of Political Economy, 108 (4): 663-679.

\footnotetext{
${ }^{16}$ Ministère de l'Economie et des Finances (2008).
} 
Behrman J.R. and B.L. Wolfe (1984), Who is Schooled in Developing Countries? The Roles of Income, Parental Schooling, Sex, Residence and Family Size. Economics of Education Review, 3 (3): 231-245.

Behrman J.R. and B.L. Wolfe (1987), Investments in Schooling in two Generations in Pre-Revolutionary Nicaragua. Journal of Development Economics, 27: 395-419.

Beegle K., R.H. Dehejia and R. Gatti (2006), Child Labor and agricultural shocks. Journal of Development Economics, 81: 80-96.

Ben-Porath Y. (1967), The Production of Human Capital and the Life-Cycle of Earnings. Journal of Political Economy, 75 (4): 352-365.

Bound J., C. Brown, and N. Mathiowetz (2001), Measurement error in survey data. In J.J. Heckman and E. Learner (eds.), Handbook of Econometrics Vol. 5 (pp. 3705-3843), Amsterdam: Elsevier Science.

Cogneau D. and R. Jedwab (2008), Household Income and Investments in Child Health and Education in Ivory Coast. Mimeo, Paris School of Economics.

Deininger K. (2003), Does cost of schooling affect enrollment by the poor? Universal primary education in Uganda. Economics of Education Review, 22: 291-305.

Glewwe P. and H.G. Jacoby (2004), Economic growth and the demand for education: is there a wealth effect? Journal of Development Economics, 74: $33-51$.

Glick P. and D.E. Sahn (2000), Schooling of girls and boys in a West African country: the effects of parental education, income and household structure. Economics of Education Review, 19: 63-87.

Grimm M. and I. Günther (2007a), Pro-Poor Growth in Burkina Faso. The role of price shocks, In M. Grimm, A. McKay and S. Klasen (Eds.), Determinants of Pro-Poor Growth: Analytical Issues and Findings from Country Cases (pp. 135-163). London: Palgrave-Macmillan.

Grimm M. and I. Günther (2007b), Growth and Poverty in Burkina Faso. A Reassessment of the Paradox. Journal of African Economies, 16: 70-101.

Grimm M. and I. Günther (2007c), Measuring pro-poor growth when relative prices shift, Journal of Development Economics, 82 (1): 245-256.

Jacoby H.G. (1994), Borrowing Constraints and Progress Through School: Evidence from Peru. Review of Economics and Statistics, 76 (1): 151160 .

Jacoby H.G. and E. Skoufias (1997), Risk, Financial Markets, and Human Capital in a Developing Country. Review of Economic Studies, 64 (3) 311-335. 
Jensen R. (2000), Agricultural Volatility and Investments in Children. American Economic Review (AEA Papers and Proceedings), 90 (2): 399-404.

Kaminski J. (2007), Réforme de la filière cotonnière burkinabè. Mimeo, Université Toulouse 1.

Kazianga H. (2005), Income Risk and Schooling Decisions in Burkina Faso. Mimeo, Earth Institute, Columbia University.

Kazianga H. and C. Udry (2005), Consumption smoothing? Livestock, insurance and drought in rural Burkina Faso. Journal of Development Economics, 79: 413-446.

Kruger D.I. (2007), Coffee production effects on child labor and schooling in rural Brazil. Journal of Development Economics, 82: 448-463.

Maccini, S. and D. Yang (2009), Under the Weather: Health, Schooling, and Economic Consequences of Early-Life Rainfall. American Economic Review, 99 (3): 1006-1026.

Ministère de l'Economie et des Finances (2008), Indice harmonisé des prix à la consommation (June 2008). Ministère de l'Economie et des Fiannces, Ouagadougou.

Ouedraogo N., A. Sanou and C. Sissao (2003), Etude de l'impact des variations du prix du coton sur la pauvreté rurale au Burkina Faso. Report prepared with support of the GTZ, Ministère de l'Economie et des Finances, Ouagadougou, Burkina Faso.

Reardon T., P. Matlon and C. Delgado (1988), Coping with Household-level Food Insecurity in Drought-affected Areas in Burkina Faso. World Development 16 (9): 1065-1074.

Rucci G. (2004) Macro Shocks and Schooling Decisions: The case of Argentina. Mimeo, University of California at Los Angeles.

Schultz T.W. (1960), Capital Formation by Education. Journal of Political Economy 68: 571-583.

Stock J.W. and M. Yogo (2002), Testing for Weak Instruments in Linear IV Regression. NBER Technical Working Papers 0284, National Bureau of Economic Research, Inc.

United Nations Development Programme (2009), Human Development Report 2009: Overcoming barriers. Human mobility and development. United Nations Development Programme, New York (Published by Palgrave Macmillan).

Yamano T., H. Alderman and L. Christiaensen (2005), Child Growth, Shocks, and Food Aid in Rural Ethiopia. American Journal of Agricultural Economics 87 (2): 273-288. 


\section{Tables and Figures}

Table 1

School enrolment, child work and real yearly household expenditure per capita (in 1000 CFA Francs, population weighted)

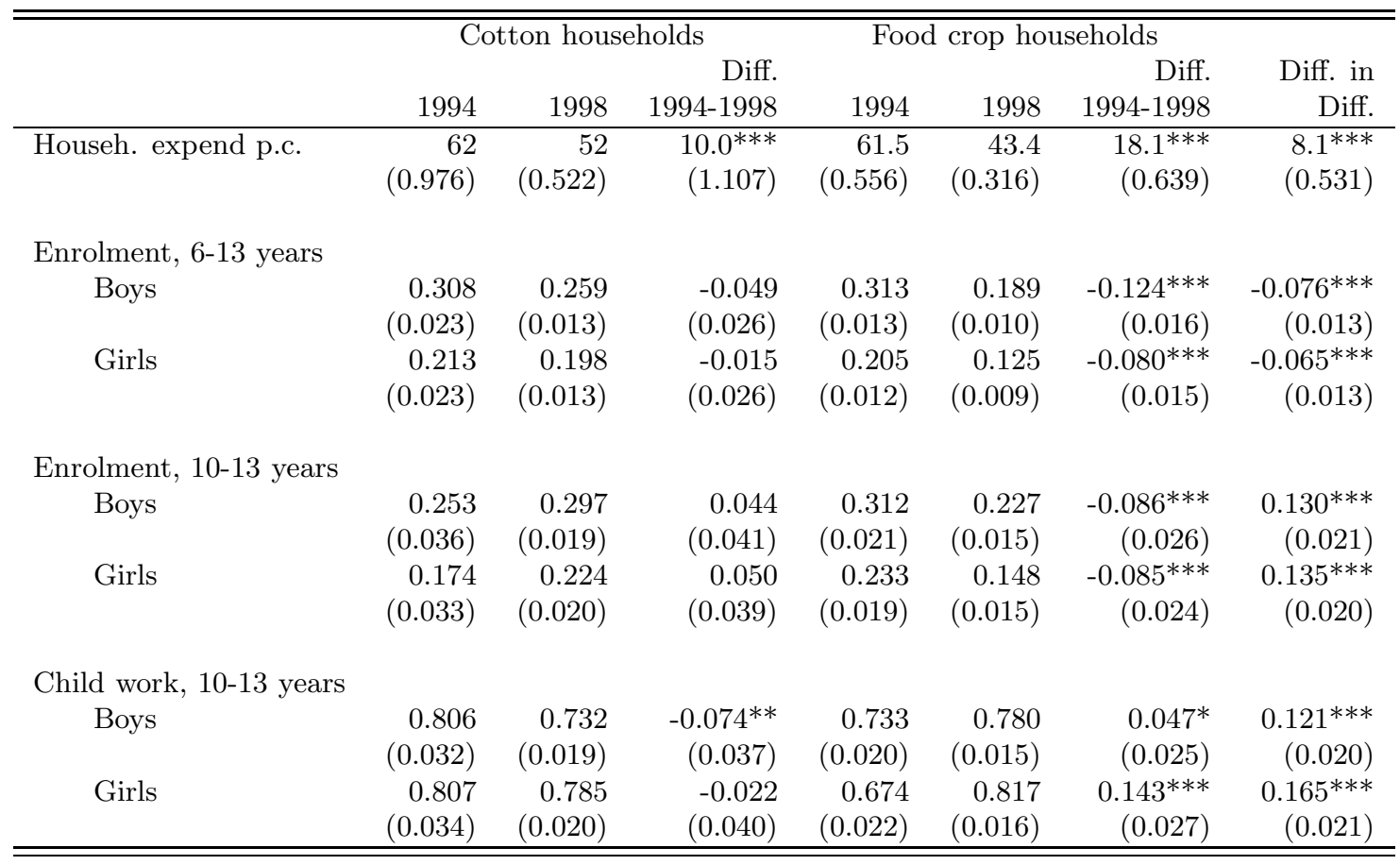

Notes: In parentheses robust standard errors of estimated means. ${ }^{*}$ significant at the $10 \%$ level, ${ }^{* *}$ significant at the $5 \%$ level, ${ }^{* * *}$ significant at the $1 \%$ level.

Source: EP1, EP2; estimations by the author. 
Table 2

Temporal pattern of differential enrolment rates and school expenditures Cotton vs. Food Crop Households

Regression effects

\begin{tabular}{|c|c|c|c|c|c|c|c|c|c|}
\hline & \multicolumn{3}{|c|}{$\begin{array}{c}\text { OLS } \\
\text { School enrolment } \\
6-13 \text { years old }\end{array}$} & \multicolumn{3}{|c|}{$\begin{array}{l}\text { Tobit } \\
\text { Schooling expend. } \\
\text { per househ. member }\end{array}$} & \multicolumn{3}{|c|}{$\begin{array}{c}\text { Tobit } \\
\text { Schooling expend. } \\
\text { per child 6-13 y. old }\end{array}$} \\
\hline & Coeff. & & S.E. & Coeff. & & S.E. & Coeff. & & S.E. \\
\hline Cotton Househ. & -0.001 & & 0.029 & 0.795 & & 0.511 & 0.989 & * & 0.566 \\
\hline Year 1998 & -0.081 & $* * *$ & 0.022 & -1.398 & $* * *$ & 0.327 & -1.401 & $* * *$ & 0.365 \\
\hline Year 2003 & -0.005 & & 0.024 & -0.305 & & 0.330 & -0.166 & & 0.367 \\
\hline Cotton $\times$ Year 1998 & 0.064 & $* *$ & 0.032 & 1.462 & $* *$ & 0.620 & 1.288 & $*$ & 0.688 \\
\hline Cotton $\times$ Year 2003 & -0.019 & & 0.033 & -0.372 & & 0.617 & -0.778 & & 0.685 \\
\hline Boy & 0.101 & $* * *$ & 0.023 & & & & & & \\
\hline Boy $\times$ Cotton & 0.011 & & 0.017 & & & & & & \\
\hline Boy $\times$ Year 1998 & -0.044 & $*$ & 0.025 & & & & & & \\
\hline Boy $\times$ Year 2003 & -0.026 & & 0.026 & & & & & & \\
\hline Household Head Male & & & & 0.513 & & 0.423 & 0.880 & $*$ & 0.476 \\
\hline Observations & & $\begin{array}{l}12273 \\
\text { hildre }\end{array}$ & & & $\begin{array}{l}6610 \\
\text { iseho }\end{array}$ & & & $\begin{array}{l}6610 \\
\text { useho }\end{array}$ & \\
\hline
\end{tabular}

Notes: Standard errors are robust to arbitrary forms of heteroskedasticity and permit withinfamily correlations among unobservables. ${ }^{*}$ significant at the $10 \%$ level, ${ }^{* *}$ significant at the $5 \%$ level, ${ }^{* * *}$ significant at the $1 \%$ level. Regression (1) also controls for age and relationship of child to household head. Intercept included but not reported here. Reference year is 1994 .

Source: EP1, EP2, EP3; estimations by the author. 
Table 3

Temporal pattern of child work

Cotton vs. Food Crop Households, Children 10 to 13 years old

Regression effects

\begin{tabular}{|c|c|c|c|c|c|c|c|c|c|}
\hline \multirow{6}{*}{$\begin{array}{l}\text { Cotton Househ. } \\
\text { Year } 1998 \\
\text { Year } 2003 \\
\text { Cotton } \times \text { Year } 1998 \\
\text { Cotton } \times \text { Year } 2003\end{array}$} & \multicolumn{3}{|c|}{$\begin{array}{c}(1) \\
\text { OLS } \\
\text { School enrolment } \\
\text { 10-13 years old } \\
\end{array}$} & \multicolumn{3}{|c|}{$\begin{array}{c}(2) \\
\text { OLS } \\
\text { Work (Def. 1) } \\
\text { 10-13 years old }\end{array}$} & $\begin{array}{c}\text { Wo } \\
10-1\end{array}$ & $\begin{array}{l}\text { (3) } \\
\text { OLS } \\
\text { k (Def } \\
\text { years }\end{array}$ & $\begin{array}{l}\text { 2) } \\
\text { old }\end{array}$ \\
\hline & -0.048 & & 0.042 & 0.112 & *** & 0.041 & 0.095 & $* *$ & 0.044 \\
\hline & -0.079 & $* *$ & 0.035 & 0.130 & $* * *$ & 0.035 & 0.168 & $* *$ & 0.035 \\
\hline & -0.014 & & 0.037 & 0.004 & & 0.038 & 0.053 & & 0.038 \\
\hline & 0.123 & $* * *$ & 0.045 & -0.136 & $* * *$ & 0.044 & -0.167 & $* * *$ & 0.047 \\
\hline & 0.031 & & 0.047 & -0.062 & & 0.047 & -0.044 & & 0.050 \\
\hline Boy & 0.080 & $* *$ & 0.036 & 0.052 & & 0.035 & 0.019 & & 0.036 \\
\hline Boy $\times$ Cotton & -0.010 & & 0.027 & -0.033 & & 0.028 & -0.013 & & 0.029 \\
\hline Boy $\times$ Year 1998 & -0.001 & & 0.038 & -0.079 & $* *$ & 0.038 & -0.065 & $*$ & 0.039 \\
\hline Boy $\times$ Year 2003 & 0.028 & & 0.041 & -0.096 & $* *$ & 0.041 & -0.092 & $* *$ & 0.042 \\
\hline Observations & & 5319 & & & 5319 & & & 5319 & \\
\hline
\end{tabular}

Notes: Standard errors are robust to arbitrary forms of heteroskedasticity and permit withinfamily correlations among unobservables. ${ }^{*}$ significant at the $10 \%$ level, ${ }^{* *}$ significant at the $5 \%$ level, ${ }^{* * *}$ significant at the $1 \%$ level. Definition 1 of 'work' assumes that children who combine school and work mainly work; definition 2 assumes that they mainly attend school. Regressions also control for age and relationship of child to household head. Intercept included but not reported here. Reference year is 1994.

Source: EP1, EP2, EP3; estimations by the author. 
Table 4

Characteristics of children (6 to 13 years old) and the households they live in (means) Initial levels, difference over time by group and differences in differences

(Differences over time are computed as $(t+1)-(t))$

\begin{tabular}{|c|c|c|c|c|c|c|c|c|}
\hline & \multirow{2}{*}{\multicolumn{2}{|c|}{$\begin{array}{c}1994 \\
\text { Level } 1994\end{array}$}} & \multicolumn{3}{|c|}{ 1994-1998 } & \multicolumn{3}{|c|}{$1998-2003$} \\
\hline & & & Diff. 19 & 4-1998 & & Diff. 19 & $8-2003$ & \\
\hline & Food crop & Cotton & Food crop & Cotton & Diff. in diff. & Food crop & Cotton & Diff. in diff. \\
\hline Age (years) & 9.054 & 9.055 & $0.148^{*}$ & 0.129 & -0.019 & 0.003 & -0.071 & $-0.074^{* * *}$ \\
\hline Boy $(=1)$ & 0.540 & 0.552 & -0.007 & -0.007 & 0.000 & $-0.019 *$ & $-0.029 * *$ & -0.010 \\
\hline Child of household head $(=1)$ & 0.783 & 0.821 & $0.089 * * *$ & $-0.048^{* * *}$ & $-0.136^{* * *}$ & 0.008 & $0.126^{* * *}$ & $0.118^{* * *}$ \\
\hline Household size $(=1)$ & 9.101 & 10.959 & -0.306 & 0.254 & 0.560 & $-0.744^{* * *}$ & $-2.145^{* * *}$ & $-1.402^{* *}$ \\
\hline Share female househ. members & 0.496 & 0.477 & 0.013 & 0.015 & 0.002 & $0.014^{* *}$ & $0.014^{*}$ & 0.000 \\
\hline Share children $6-13$ in household & 0.294 & 0.277 & $0.029 * * *$ & 0.012 & -0.016 & -0.008 & 0.009 & 0.017 \\
\hline Household head male $(=1)$ & 0.914 & 0.967 & 0.005 & 0.007 & 0.002 & $-0.023^{*}$ & 0.004 & 0.027 \\
\hline Household head age (years) & 46.358 & 45.229 & 1.352 & $2.089^{* *}$ & 0.737 & 0.119 & -1.058 & -1.178 \\
\hline Household head migr. last 5 years $(=1)$ & 0.062 & 0.025 & 0.004 & $0.030^{*}$ & 0.026 & n.a. & n.a. & n.a. \\
\hline Household head some primary $(=1)$ & 0.061 & 0.089 & -0.001 & 0.001 & 0.002 & 0.006 & 0.007 & 0.001 \\
\hline Household head primary compl. $(=1)$ & 0.028 & 0.056 & 0.001 & -0.001 & -0.002 & 0.001 & 0.002 & 0.001 \\
\hline Spouse of head some primary $(=1)$ & 0.045 & 0.054 & 0.002 & -0.003 & -0.004 & 0.000 & 0.007 & 0.008 \\
\hline
\end{tabular}

Notes: The means of 'Age', 'Boy' and 'Child of household head' are computed over all children. The remaining variables are means over all households to which the children belong. ${ }^{*}$ difference significant at the $10 \%$ level, ${ }^{* *}$ difference significant at the $5 \%$ level, ${ }^{* * *}$ difference significant at the $1 \%$ level.

Source: EP1, EP2, EP3; computations by the author. 
Table 5

The income elasticity of school enrolment, $1994-1998$ Children 6 to 13 years old

\begin{tabular}{|c|c|c|c|c|c|c|c|c|c|c|c|c|}
\hline & \multicolumn{3}{|c|}{$\begin{array}{c}(1) \\
\text { OLS }\end{array}$} & \multicolumn{3}{|c|}{$\begin{array}{c}(2) \\
2 \text { SLS }\end{array}$} & \multicolumn{3}{|c|}{$\begin{array}{c}(3) \\
\text { OLS }\end{array}$} & \multicolumn{3}{|c|}{$\begin{array}{c}(4) \\
2 \text { SLS }\end{array}$} \\
\hline & Coeff. & & S.E. & Coeff. & & S.E. & Coeff. & & S.E. & Coeff. & & S.E. \\
\hline \multicolumn{13}{|l|}{ BOYS } \\
\hline \multicolumn{13}{|l|}{ Main equation } \\
\hline Cotton Househ. & -0.013 & & 0.023 & -0.042 & & 0.034 & -0.012 & & 0.022 & -0.047 & & 0.033 \\
\hline Year 1998 & -0.100 & $* * *$ & 0.019 & -0.116 & $* * *$ & 0.022 & -0.093 & $* * *$ & 0.018 & -0.112 & $* * *$ & 0.021 \\
\hline Ln Expenditure (IV) & 0.073 & $* * *$ & 0.012 & 0.220 & $*$ & 0.126 & 0.067 & $* * *$ & 0.012 & 0.248 & $* *$ & 0.127 \\
\hline HH head some primary & & & & & & & 0.102 & $* * *$ & 0.034 & 0.093 & $* * *$ & 0.035 \\
\hline Spouse some primary & & & & & & & 0.205 & $* * *$ & 0.054 & 0.157 & $* * *$ & 0.056 \\
\hline Age effects & & yes & & & yes & & & yes & & & yes & \\
\hline Additional controls (see note) & & no & & & no & & & yes & & & yes & \\
\hline Province fixed-effects & & yes & & & yes & & & yes & & & yes & \\
\hline \multicolumn{13}{|l|}{$\begin{array}{l}\text { First stage } \\
\text { IV: Being a cotton } \\
\text { farmer in } 1998\end{array}$} \\
\hline$F$-Stat & & & & & 24.1 & & & & & & 26.7 & \\
\hline Observations & & 4359 & & & 4359 & & & 4359 & & & 4359 & \\
\hline
\end{tabular}

Notes: See next page. 
Table 5 (... continued.)

\begin{tabular}{|c|c|c|c|c|c|c|c|c|c|c|c|c|}
\hline & \multicolumn{3}{|c|}{$\begin{array}{c}(5) \\
\text { OLS }\end{array}$} & \multicolumn{3}{|c|}{$\begin{array}{c}(6) \\
2 \text { SLS }\end{array}$} & \multicolumn{3}{|c|}{$\begin{array}{c}(7) \\
\text { OLS }\end{array}$} & \multicolumn{3}{|c|}{$\begin{array}{c}(8) \\
2 S L S\end{array}$} \\
\hline & Coeff. & & S.E. & Coeff. & & S.E. & Coeff. & & S.E. & Coeff. & & S.E. \\
\hline \multicolumn{13}{|l|}{ GIRLS } \\
\hline \multicolumn{13}{|l|}{ Main equation } \\
\hline Cotton Househ. & 0.012 & & 0.022 & -0.048 & & 0.041 & 0.007 & & 0.022 & -0.038 & & 0.034 \\
\hline Year 1998 & -0.054 & $* * *$ & 0.018 & -0.081 & $* * *$ & 0.023 & -0.047 & $* * *$ & 0.018 & -0.074 & $* * *$ & 0.022 \\
\hline Ln Expenditure (IV) & 0.016 & & 0.012 & 0.334 & $*$ & 0.178 & 0.019 & & 0.012 & 0.297 & $*$ & 0.160 \\
\hline HH head some primary & & & & & & & 0.147 & $* * *$ & 0.039 & 0.147 & $* * *$ & 0.035 \\
\hline Spouse some primary & & & & & & & 0.128 & $* * *$ & 0.047 & 0.134 & $* * *$ & 0.048 \\
\hline Age effects & & yes & & & yes & & & yes & & & yes & \\
\hline Additional controls (see note) & & no & & & no & & & yes & & & yes & \\
\hline Province fixed-effects & & yes & & & yes & & & yes & & & yes & \\
\hline
\end{tabular}

First stage

IV: Being a cotton

farmer in 1998

\begin{tabular}{llccc}
$F$-Stat & & 13.5 & 16.2 & 3708 \\
\hline Observations & 3708 & 3708 & 3708 \\
\hline \hline
\end{tabular}

Notes: Standard errors are robust to arbitrary forms of heteroskedasticity and permit within-family correlations among unobservables. ${ }^{*}$ significant at the $10 \%$ level, ${ }^{* *}$ significant at the $5 \%$ level, ${ }^{* * *}$ significant at the $1 \%$ level. Additional controls (cols. (3), (4), (7) and (8) include being the eldest child in the household, being a child of the household head, the share of female household members, the share of children 6-13 years old in the household and whether the household head is a male. Intercept included but not reported here. The first-stage regression includes also all other variables from the main equation as instruments. Base year for year effects is 1994 .

Source: EP1, EP2, EP3; estimations by the author. 
Table 6

The income elasticity of school enrolment, 1994 - 1998 - Robustness checks Children 6 to 13 years old

\begin{tabular}{|c|c|c|c|c|c|c|c|c|c|c|c|c|}
\hline & \multicolumn{6}{|c|}{$\overline{\overline{\text { Boys }}}$} & \multicolumn{6}{|c|}{$\overline{\text { Girls }}$} \\
\hline & \multirow{2}{*}{\multicolumn{3}{|c|}{$\begin{array}{l}(1) \\
\text { OLS }\end{array}$}} & \multirow{2}{*}{\multicolumn{3}{|c|}{$\begin{array}{c}(2) \\
2 \mathrm{SLS}\end{array}$}} & \multirow{2}{*}{\multicolumn{3}{|c|}{$\begin{array}{c}(3) \\
\text { OLS }\end{array}$}} & \multirow{2}{*}{\multicolumn{3}{|c|}{$\begin{array}{c}(4) \\
2 \text { SLS }\end{array}$}} \\
\hline & & & & & & & & & & & & \\
\hline & Coeff. & & S.E. & Coeff. & & S.E. & Coeff. & & S.E. & Coeff. & & S.E. \\
\hline \multicolumn{13}{|c|}{ Interaction term: Household was not a cotton household in previous year } \\
\hline Cotton Househ. & -0.016 & & 0.024 & -0.053 & & 0.036 & -0.014 & & 0.023 & -0.053 & & 0.035 \\
\hline Cotton $\times$ No Cott. in $t-1$ & 0.016 & & 0.033 & 0.043 & & 0.035 & 0.088 & $* *$ & 0.037 & 0.096 & $* * *$ & 0.032 \\
\hline Ln Expenditure (IV) & 0.067 & $* * *$ & 0.012 & 0.227 & $* *$ & 0.116 & 0.019 & & 0.012 & 0.251 & $*$ & 0.155 \\
\hline First stage $F$-Stat & & & & & 30.6 & & & & & & 16.5 & \\
\hline
\end{tabular}

Cotton households having not been a cotton household in previous year are merged with food-crop farmers ${ }^{a}$

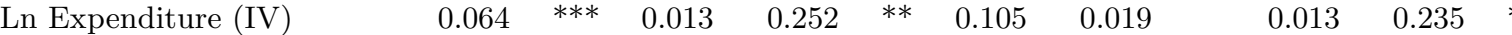

First stage $F$-Stat $\quad 38.1 \quad 22.9$

0.131

First stage $F$-Stat

\begin{tabular}{llllllllllll} 
Ln Expenditure (IV) & 0.068 & $* * *$ & 0.013 & 0.230 & $*$ & 0.138 & 0.022 & $*$ & 0.013 & 0.261 & \\
First stage $F$-Stat & & & \multicolumn{2}{c}{0.178}
\end{tabular}

First stage $F$-Stat 20.2

Cotton households having produced less than $250 \mathrm{~kg}$ cotton merged with food-crop farmers ${ }^{c}$

\begin{tabular}{llllllllllllll} 
Ln Expenditure (IV) & 0.063 & $* * *$ & 0.013 & 0.465 & & 0.301 & 0.021 & $*$ & 0.013 & 0.502 & $* *$ & 0.248 \\
First stage $F$-Stat & & & & 5.6 & & & & & & & \\
\hline
\end{tabular}

Notes: Standard errors are robust to arbitrary forms of heteroskedasticity and permit within-family correlations among unobservables. ${ }^{*}$ significant at the $10 \%$ level, ${ }^{* *}$ significant at the $5 \%$ level, ${ }^{* * *}$ significant at the $1 \%$ level. Regressions correspond to those presented in Table 5 (columns (3), (4), (7) and (8)).

${ }^{a}$ Procedure re-allocates 6.45 percent of all boys and 7.18 percent of all girls. ${ }^{b}$ Procedure re-allocates 3.66 percent of all boys and 3.42 percent of all girls. ${ }^{c}$

Procedure re-allocates 8.71 percent of all boys and 8.44 percent of all girls.

Source: EP1, EP2, EP3; estimations by the author. 
Figure 1

Production of main cereals and cotton (in tons)

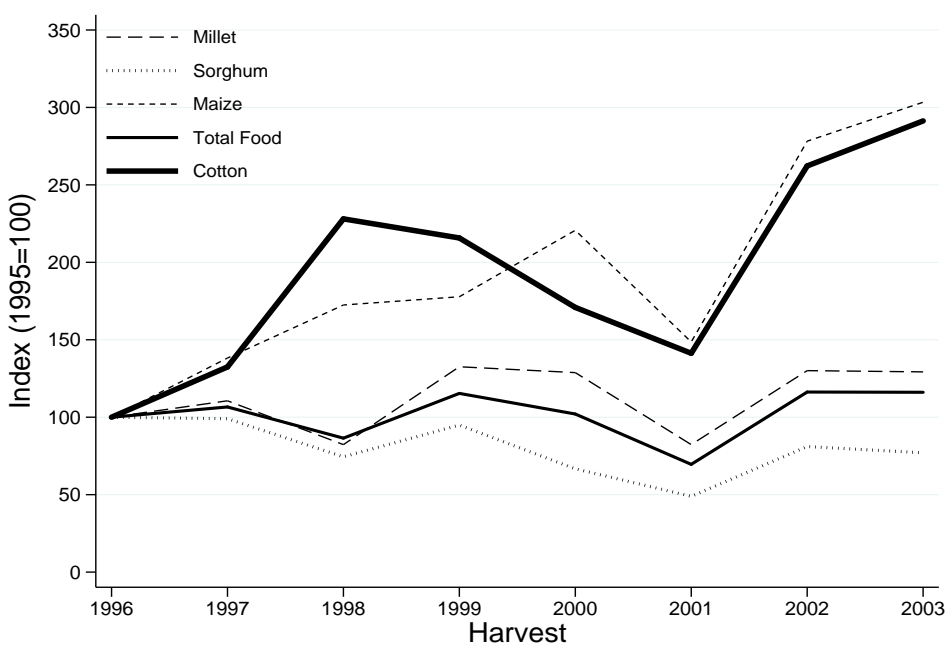

Notes: Total food means tons of millet, sorghum and maize.

Source: Economic Accounts for the Agricultural Sector, based on Enquête Agricole (data not available for harvests before 1996).

Figure 2

Consumer prices of main cereals and cotton producer price

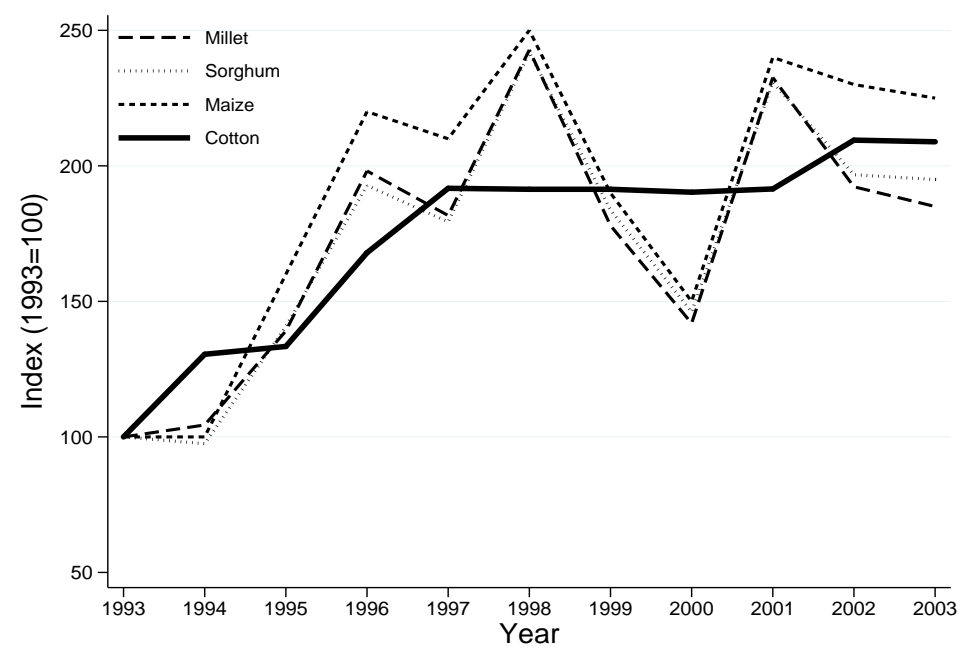

Notes: Annual average prices (collected on 37 different regional markets).

Source: Cereal prices: Grain Market Price Surveillance System, Ministry of Trade. Cotton price: Ouedraogo, Sanou and Sissao (2003). 